\title{
Pytoremediation of fluoroquinolone group of antibiotics from waste water
}

\author{
Shalini A. Tandon ${ }^{1 *}$, Rakesh Kumar ${ }^{1}$, Rupneet K. Bajwa ${ }^{2}$, Suman A. Yadav ${ }^{3}$ \\ ${ }^{1}$ National Environmental Engineering Research Institute (N.E.E.R.I.), Mumbai Zonal Laboratory, Mumbai, India; \\ ${ }^{*}$ Corresponding Author: tandon.shalini@gmail.com \\ ${ }^{2}$ Guru Nanak Khalsa College of Arts, Science and Commerce, Mumbai, India \\ ${ }^{3}$ SIES College of Arts, Science and Commerce, Mumbai, India
}

Received 22 October 2013; revised 22 November 2013; accepted 29 November 2013

Copyright (C) 2013 Shalini A. Tandon et al. This is an open access article distributed under the Creative Commons Attribution License, which permits unrestricted use, distribution, and reproduction in any medium, provided the original work is properly cited.

\section{ABSTRACT}

The study involved selection of wetland plant species hyper efficient in removing fluoroquinolone group of antibiotics so that they can be used in a constructed wetland system patented by NEERI, India (European Patent Office (EPO) Pub. No.: WO2004087584) or any other constructed wetland. Phyto removal of these antibiotics at such high concentrations without any toxic effect on the plant species is very useful as incomplete removal of certain antibiotics such as Ciprofloxacin, and Ofloxacin from waste waters is of concern due to their health effects if they do persist in finished waters even at $\mathrm{ng} / \mathrm{l}$ levels. Five different wetland plant species which were also tested for their efficiency to treat municipal wastewater were used to test their efficiency to scavenge commonly used fluoroquinolone antibiotics (which are not degraded easily) namely Ciprofloxacin, Gemifloxacin mesylate, Ofloxacin and Gatifloxacin from aqueous medium (Hoagland-Arnon solution). EC double beam UV-VIS spectrophotometer was used to obtain lambda max of Ciprofloxacin, Gemifloxacin mesylate, Ofloxacin and Gatifloxacin in Hoagland-Arnon solution. The most efficient plant species for each antibiotic were selected and tested again for confirmation of antibiotic removal efficiency at a high concentration of $\mathbf{5 0}$ $\mathrm{mg} / \mathrm{l}$ of each antibiotic. Taxodium distichum was found to be the most suitable for the removal of Ofloxacin, Gatifloxacin and Ciprofloxacin showing maximum removal of $32 \mathrm{mg} / \mathrm{l}$ (on $6^{\text {th }}$ day), 21 $\mathrm{mg} / \mathrm{l}$ (on $8^{\text {th }}$ day), $32 \mathrm{mg} / \mathrm{ll}$ (on $9^{\text {th }}$ day), respectively and Canna indica was found to be the most suitable for removal of Gemifloxacin me- sylate showing maximum removal of $38 \mathrm{mg} / \mathrm{l}$ (on $8^{\text {th }}$ day).

Keywords: Constructed Wetland; Waste Water Treatment; Wetland Plant Species; Fluoroquinolone

\section{INTRODUCTION}

Pharmaceuticals and personal care products (PPCPs) have been extensively used for decades for various purposes ranging from personal health, cosmetic reasons to veterinary purposes [1]. They are members of a group of chemicals of emerging concern as increasing evidence suggests their ubiquity in the environment and potential adverse effects on non-target organisms and humans [2-4]. The main reason why those pharmaceuticals may become harmful to the environment is that they are designed to affect biological objects. They have lipophilicity, which enables them to permeate biomembranes, and stability, which prevents their inactivation. This enables them to accumulate in organisms and cause changes in water and soil ecosystems [5]. Occurrence of antibiotics was also investigated in water associated with two hospitals in Ujjain district, India and concentration of ciprofloxacin which is one of the most prominent antibiotics used, was detected to be as high as $31 \mathrm{mg} / \mathrm{l}$ [6]. Depending on the drug, $12 \%-90 \%$ of them pass through sewage treatment plants unaltered [7]. Thus, it can be concluded that treatment facilities do not remove drug residue completely.

\subsection{Environmental Occurrence}

Fate of drug residue after entering a treatment facility may be one of the following: 1) the substance is easily degradable and decomposes fast and fully into $\mathrm{CO}_{2} ; 2$ ) the substance is lipophilic and doesn't degrade easily; or 
3) the substance is metabolized into a more hydrophilic matter but does not degrade at all, instead passes through the treatment plant and enters the aqueous environment [8]. The presence of a broad range of antibiotics even at low occurrence level of each individual drug in source waters suggests that the overall effect of antibiotics as a contaminant group should not be underestimated. The incomplete removal of certain antibiotics such as ciprofloxacin, ofloxacin, is of concern due to their unknown health effects if they do persist in finished waters even at $\mathrm{ng} / \mathrm{l}$ levels. Considerable amount of drugs entering surface water and ending up in drinking water as is the case in the United States where antibiotics were detected in the range of $18-70 \mathrm{ng} / \mathrm{l}$ in source and finished water [9]. In soils irrigated with reclaimed water, pharmaceuticals have been detected with typical concentrations ranging from 0.02 - 15 microgram per kilogram of soil [10]. Pharmaceuticals and other anthropogenic organic contaminants have also been reported in agricultural soils, several compounds being detected in earthworms from applied sites [11].

Fluoroquinolone is a group of drugs that remain in the environment for a long period of time. Synthetic and semi-synthetic antibacterial substances are mostly "strangers" to nature and difficult to degrade and their residence time in the environment depends on the structure of the molecules [12]. One reason for slow degradation of fluoroquinolones can be contributed to their strong adsorption to manure and soil [13]. Untreated or partially treated sewage also enters the water bodies and the pathogenic bacteria are subjected to chronic exposures to antibiotics and thus develop resistance. The mechanism of action of all the quinolones and fluoro- quinolones against bacteria is similar, thus resistance to any one of the antibiotics belonging to this group would confer simultaneous cross-resistance to other quinolone and fluoroquinolone drugs [14]. Modifications in strains of the bacteria Salmonella typhimurium have been reported at a concentration as low as $25 \mu \mathrm{g} / \mathrm{l}$ for ciprofloxacin $[15,16]$. Hence, it has become extremely important for removal of such drugs from soils and water before the organisms attain resistance to it.

\subsection{Fate in Plants}

A number of antibiotics have been demonstrated to be absorbed by the roots of plants and translocated to stems and leaves [17]. It was also observed that Streptomycin persisted in plants for more than eight weeks [18]. In some cases, antibiotics were shown to be inactivated and metabolized in plants $[19,20]$. The extent and type of injury vary with the nature and concentration of the antibiotic tested. Likewise, different plants vary in their susceptibility to injury by any one antibiotic at a given concentration. Usually root growth and shoot growth are inhibited more severely than seed germination. Plants devoid of chlorophyll, due to presence of antibiotic, could either be due to the destruction of chloroplast or due to failure of chlorophyll synthesis.

\subsection{Treatment for Removal and Analytical Methodology}

Traditional treatment practices include oxidation ponds, storage ponds, land spreading and composting [21]. Although these processes are simple, cost-effective and require less energy, they have the disadvantage of high dependence on local climate, secondary pollution of ground water and occupation of large area [22]. In recent years, the use of aquatic plants for phytoremediation of different types of wastewater has increased due to their high potential for removing and recovering nutrients, easy harvesting of plants and the high productivity [22]. Most of the previous studies focused on the use of phytoremediation for reducing nitrogen and phosphorus contamination of surface and ground water but reports on the removal of antibiotics from wastewater by plants are limited [23]. Regarding analytical methodology, a study by Amjad et al. (2005) on residual antibiotics in tissues showed good compatibility of the spectrophotometric results with those found with HPLC. Likewise, Dey et al. (2010) estimated flucloxacillin by UV-VIS Spectrophotometric method [24]. Mendez et al. (2003) studied the validation of HPLC and UV spectrophotometric methods for the determination of meropenem and found no significant difference between the results obtained by the two methods [25].

The purpose of this study was to select wetland plant species which were able to deal with high concentrations of antibiotics belonging to fluoroquinolone group namely Ciprofloxacin, Gemifloxacin mesylate, Ofloxacin and Gatifloxacin without any toxic effect in terms of adverse effect on their growth and morphology and were also able to treat municipal waste water for further using these plants in a constructed wetland system patented by NEERI, India (European Patent Office (EPO) Pub. No.: WO2004087584) or any other constructed wetland.

\section{MATERIALS AND METHODS}

\subsection{Materials}

Pharmaceutical grade fluoroquinolones i.e. Ciprofloxacin $(500 \mathrm{mg})$, Gemifloxacin mesylate $(320 \mathrm{mg})$, Ofloxacin $(200 \mathrm{mg})$ and Gatifloxacin $(400 \mathrm{mg})$ which are widely used in India were used. Five different types of commonly found wetland plant species which have been used in constructed wetland systems were obtained from a nearby plant nursery. These plants were Chrysopogon zizanioides, Pistia stratiotes, Taxodium distichum, Colocasia esculenta and Canna indica [26,27]. These wetland 
plants were commonly available and well adapted to the local climatic conditions. Hoagland-Arnon solution was the hydroponic solution used to support the plants growth. Chemicals used for conventional wastewater parametric analysis were as per the norms of APHA [28].

\subsection{Description of the System}

The experiment was carried out with five different emergent wetland plant species. They were first checked for the efficiency of removal of $\mathrm{COD}, \mathrm{BOD}, \mathrm{NO}_{3}-\mathrm{N}$ and $\mathrm{PO}_{4}-\mathrm{P}$ in municipal waste water and then the same plant species were tested for the removal of four different antibiotics belonging to the family of fluoroquinolones. All the plant species were then kept in small clean mesocosms containing Hoagland-Arnon nutrient solution spiked with high concentration of $50 \mathrm{mg} / \mathrm{l}$ of each antibiotic, mainly because occurrence of antibiotics was investigated in water associated with two hospitals in Ujjain district, India and concentration of ciprofloxacin which is one of the most prominent antibiotics, was detected to be as high as $31 \mathrm{mg} / 1$ [29]. In order to cover areas ranging from hospital effluents to source drinking water, a higher concentration of $50 \mathrm{mg} / \mathrm{l}$ was selected for the experiment. Also, the plants which are efficient in removing higher concentration $(50 \mathrm{mg} / \mathrm{l})$ of antibiotics can also deal with lower levels of antibiotic concentrations in the environment. The antibiotic concentration remaining in the Hoagland-Arnon solution was determined till 25 days. Biomass of all the plants was weighed before and at the end of 25 days and any morphological changes were also recorded.

After the screening, two plant species showing the best efficiency for each antibiotic were selected and the above step was repeated again in a set of triplicates for further confirmation.

\subsection{Preparation of Standard Solutions}

Standard stock solutions for all the four antibiotics were prepared by dissolving $500 \mathrm{mg}$ of the antibiotic tablet in one liter of modified Hoagland-Arnon solution (6.0 $\mathrm{mM} \mathrm{KNO}{ }_{3} ; 4.0 \mathrm{mM} \mathrm{Ca}\left(\mathrm{NO}_{3}\right)_{2} ; 1.0 \mathrm{mM} \mathrm{NH}_{4} \mathrm{H}_{2} \mathrm{PO}_{4} ; 2.0$ $\mathrm{mM} \mathrm{MgSO}_{4} ; 3.0 \mu \mathrm{M} \mathrm{H}_{3} \mathrm{BO}_{3} ; 0.5 \mu \mathrm{M} \mathrm{MnSO}_{4} ; 0.2 \mu \mathrm{M}$ $\mathrm{CuSO}_{4} ; 0.4 \mu \mathrm{M} \mathrm{ZnSO}_{4}, 0.05 \mu \mathrm{M} \mathrm{H}_{2} \mathrm{MoO}_{4}$ and $20.0 \mu \mathrm{M}$ EDTA-Fe $^{3+}$ ) [30].

The stock solution was further diluted with HoaglandArnon media in order to get a working standard solution of required concentration. This solution was used as standard working solution. The solvent used throughout the experiment was distilled water.

\subsection{Sampling Regime}

Each of the five plants were kept in 6 liters of municipal waste water in a floating wetland system. $150 \mathrm{ml}$ of municipal waste water sample was taken every third day for analysis which was carried out for ten days and parameters such as COD (Chemical Oxygen Demand), BOD (Biological Oxygen Demand), $\mathrm{NO}_{3}-\mathrm{N}$ and $\mathrm{PO}_{4}-\mathrm{P}$ were analyzed. The next step involved analysis of water samples from each antibiotic solution containing respective plant species in the initial screening as well as in the final confirmatory analysis every 24 hours during the 25 days of experimental period, respectively. These samples were used for the analysis of antibiotics in the nutrient solution. During the sampling campaign the average temperature was $28^{\circ} \mathrm{C}$ degrees with a minimum of $25^{\circ} \mathrm{C}$ and a maximum of $31^{\circ} \mathrm{C}$.

\subsection{Analysis of Antibiotics}

EC double beam UV-VIS spectrophotometer supported by Windows based Spectrum software was used for analysis with one centimeter path length for all the spectrophotometric estimations. Regarding analytical methodology, a study by Amjad et al. 2005 on residual antibiotics in tissues showed good compatibility of the spectrophotometric results with those found with HPLC [31]. Dey et al. (2010) estimated Flucloxacillin by UVVIS Spectrophotometric method. Mendez et al. 2003 studied the Validation of HPLC and UV spectrophotometric methods for the determination of Meropenem and found no significant difference between the results obtained by the two methods.

From the working stock solutions, appropriate dilutions of each antibiotic were made with Hoagland-Arnon solution. Solutions were scanned in the wavelength range of $400-200 \mathrm{~nm}$ and recorded the UV spectrum of each antibiotic using Arnon-Hoagland solution in the reference cell as a blank. Absorbance maxima $\left(\lambda_{\max }\right)$ for $\mathrm{Ci}$ profloxacin, Gemifloxacin mesylate, Gatifloxacin, Ofloxacin was found to be $276 \mathrm{~nm}, 270 \mathrm{~nm}, 291 \mathrm{~nm}, 292$ $\mathrm{nm}$, respectively. The obtained absorbance maxima was then confirmed on Shimadzu UV-1650 PC supported by UV Probe 2.31 software which gave results with same wavelengths of respective antibiotics as mentioned above.

\section{RESULTS AND DISCUSSION}

Phytoremediation efficiency of emergent wetland plant species, Chrysopogon zizanioides, Pistia stratiotes, Taxodium distichum, Colocasia esculenta and Canna indica, were analyzed in a floating wetland with primary treated municipal waste water, for 10 days. It was observed that all the plant species were efficient in waste water treatment (Table 1) and so they could be used to test for their antibiotic removal efficiency thereby playing a dual role in municipal waste water treatment in our patented constructed wetland system NEERI, India (Euro pean Patent 
Table 1. Characteristics (in mg/l) of municipal waste water (MSW) treated by the five wetland plant species.

\begin{tabular}{ccccccccc}
\hline Column 1 & Column 2 & Column 3 & Column 4 & Column 5 & Column 6 & Column 7 & Column 8 \\
\hline $\mathrm{mg} / 1$ & raw MSW & Unplanted & C.zizanoides & P.stratiotes & T.distichum & C.esculenta & C.indica \\
$\mathrm{BOD}$ & 200 & 85 & 50 & 69 & 55 & 71 & 64 \\
$\mathrm{COD}$ & 320 & 200 & 80 & 10 & 100 & 120 & 100 \\
$\mathrm{NO}_{3}-\mathrm{N}$ & 0.62 & 0.56 & 0.37 & 0.35 & 0.34 & 0.41 & 0.4 \\
$\mathrm{PO}_{4}-\mathrm{P}$ & 0.077 & 0.061 & 0.05 & 0.054 & 0.047 & 0.058 & 0.06 \\
\hline
\end{tabular}

Office (EPO) Pub. No.: WO2004087584).

\subsection{Screening Study}

\subsubsection{Plant Morphological and Growth Responses}

The objective of this study was to select efficient wetland plant species for the removal of high concentration of antibiotics without nay adverse effect on their growth and morphology. In the presence of Ciprofloxacin and Gemifloxacin mesylate, Chrysopogon zizanioides and Taxodium distichum showed healthy response but Colocasia esculenta exhibited leaf abscission while chlorosis was observed in Canna indica. In the presence of Ofloxacin, diffused chlorosis, veinal chlorosis and interveinal chlorosis was seen in Chrysopogon zizanioides, Colocasia esculenta and Canna indica, respectively. Colocasia esculenta showed marginal and veinal chlorosis and Canna indica showed diffused Chlorosis when kept in Gatifloxacin and both Colocasia esculenta and Canna indica showed leaf abscission when grown in Gatifloxacin and Ofloxacin. Necrosis of Pistia sratiotes was seen in all the 4 antibiotics.

The plants responded variably in terms of their change in weight in response to these antibiotics during the test period. In the presence of Ciprofloxacin, increase in weight of Chrysopogon zizanioides (30.8 g), Taxodium distichum $(28.8 \mathrm{~g})$ was observed whereas Colocasia esculenta (-6.2 g) and Canna indica (-0.8 g) showed decrease in weight. In case of Gemifloxacin mesylate Chrysopogon zizanioides $(23 \mathrm{~g})$, Taxodium distichum $(20$ g), Colocasia esculenta (7.8 g) and Canna indica (15.8 g) showed increase in weight. Increase in weight was observed in Chrysopogon zizanioides (19 g), Taxodium distichum $(40.2 \mathrm{~g})$ while Canna indica $(-0.8 \mathrm{~g})$ showed decrease in weight in case of Ofloxacin. In the presence of Gatifloxacin Chrysopogon zizanioides (13 g), Taxodium distichum (10.6 g), Colocasia esculenta (2.8 g) showed increase in weight and Canna indica $(-4 \mathrm{~g})$ showed reduction in weight. Along with the above observation, Mucilage formation (i.e. protective sheath around roots and stems) was seen in Colocasia esculenta grown in Ofloxacin for which antibiotic sensitivity test (AST) by disc diffusion method was performed and dis- tinct zone of growth inhibition of the test organism around pieces of tissues(mucilage) was observed, indicating presence of antibiotic in the mucilage (plate 1).

For Ciprofloxacin, Chrysopogon zizanioides and Taxodium distichum; for Gemifloxacin mesylate-Taxodium distichum and Canna indica, for Ofloxacin and Gatifloxacin Taxodium distichum and Colocasia esculenta showed best removal efficiency (Figures 1-4). However, Colocasia esculenta was not used for further study as it showed mucilage formation around the root region which had a negative impact on plant's overall growth.

\subsubsection{Confirmatory Study Using the Selected Plant Species}

The two selected wetland plant species showing best antibiotic removal efficiency and exhibiting no adverse effect on their growth and morphology were again analyzed in a floating system by repeating the method used for the selection study. All the plants in each antibiotic solution showed healthy response. Leaf abscission was observed in none of the plants species while Chlorosis was observed in Canna indica. Taxodium distichum showed $64 \%$ removal efficiency for Ofloxacin, $42 \%$ for Gatifloxacin and $64 \%$ for Ciprofloxacin whereas removal efficiency of Canna indica for Gemifloxacin mesylate was $76 \%$ for $50 \mathrm{mg} / \mathrm{l}$ of the antibiotic concentration. In control there was no significant removal of antibiotic. Taxodium distichum was found to be the most suitable for the removal of Ofloxacin, Gatifloxacin and Ciprofloxacin showing maximum removal of $32 \mathrm{mg} / \mathrm{l}$ (on $6^{\text {th }}$ day being the first day of maximum removal which was constant on later days of the test period, DMCR), 21 $\mathrm{mg} / \mathrm{l}$ (on $8^{\text {th }}$ day as DMCR), $32 \mathrm{mg} / \mathrm{l}$ (on $9^{\text {th }}$ day as DMCR), respectively and Canna indica was found to be the most suitable for removal of Gemifloxacin mesylate showing maximum removal of $38 \mathrm{mg} / 1$ (on $8^{\text {th }}$ day as DMCR) (Table 2). On doing analysis of variance (ANOVA) there was significant difference in the removal of the antibiotics by the selected plant species over control (unplanted) (Table 3). Hence, the selected plant species were efficient in the removal of high concentrations of the antibiotics from the solution and different plant species showed different removal efficiencies for these 
Table 2. The day of maximum removal (DMR) and the concentration of antibiotics removed (mg/l) by the selected wetland plant species.

\begin{tabular}{|c|c|c|c|c|c|c|c|c|}
\hline Column 1 & Column 2 & Column 3 & Column 4 & Column 5 & Column 6 & Column 7 & Column 8 & Column 9 \\
\hline & \multicolumn{2}{|c|}{ Ciprofloxacin } & \multicolumn{2}{|c|}{ Gemifloxacin } & \multicolumn{2}{|c|}{ Ofloxacin } & \multicolumn{2}{|c|}{ Gatifloxacin } \\
\hline & \multicolumn{2}{|c|}{ DMR Removal } & \multicolumn{2}{|c|}{ DMR Removal } & \multicolumn{2}{|c|}{ DMR Removal } & \multicolumn{2}{|c|}{ DMR Removal } \\
\hline TD & 8 & $36( \pm 1)$ & 10 & $24( \pm 0.68)$ & 6 & $30( \pm 0.58)$ & 8 & $23( \pm 1)$ \\
\hline $\mathrm{CI}$ & * & * & 8 & $28( \pm 0.89)$ & * & * & * & * \\
\hline $\mathrm{CZ}$ & 4 & $24( \pm 5)$ & $*$ & * & * & * & * & $*$ \\
\hline
\end{tabular}

TD: Taxodium distichum; CI: Canna indica; CZ: Chrysopogon zizanioides. ${ }^{*}$ no significant results obtained.

Table 3. ANOVA table showing significant difference in antibiotic removal by the plant species for each antibiotic.

$\begin{array}{ccccc} & \text { ANOVA } & & \\ & d f & \text { MS } & \text { F } & P \text { value } \\ \begin{array}{c}\text { Between TD, CZ, control } \\ \text { (Ciprofloxacin) }\end{array} & 2 & 5745 & 123 & 5.45 \mathrm{E}-22 \\ \begin{array}{c}\text { Between TD, CI, control } \\ (\text { Gemifloxacin) }\end{array} & 2 & 3472 & 74.9 & 4.84 \mathrm{E}-17 \\ \begin{array}{c}\text { Between TD and control } \\ \text { (Ofloxacin) }\end{array} & 1 & 6738 & 220 & 7.23 \mathrm{E}-18 \\ \begin{array}{c}\text { Between TD and control } \\ \text { (Gatifloxacin) }\end{array} & 1 & 4245 & 299 & 3.44 \mathrm{E}-20\end{array}$

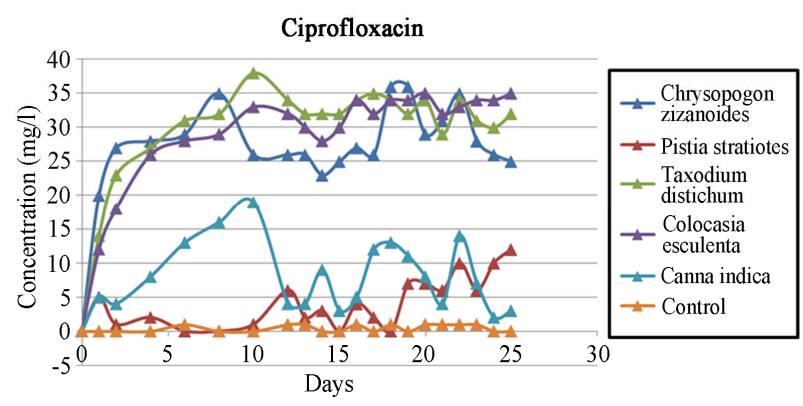

Figure 1. Ciprofloxacin removed (mg/l) from hydroponic system with various wetland plant species.

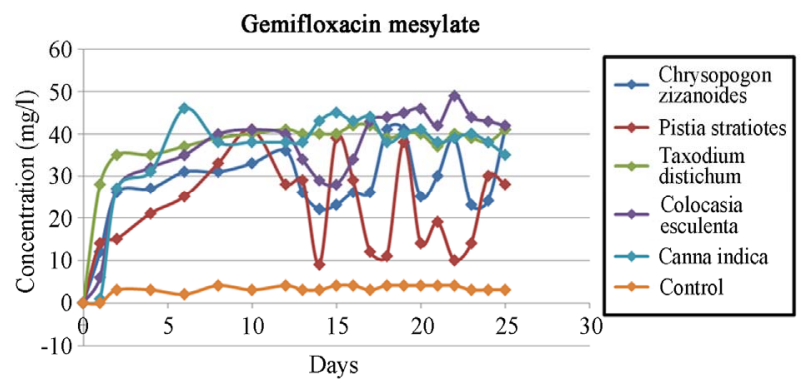

Figure 2. Gemifloxacin removed (mg/l) from hydroponic system with various wetland plant species.

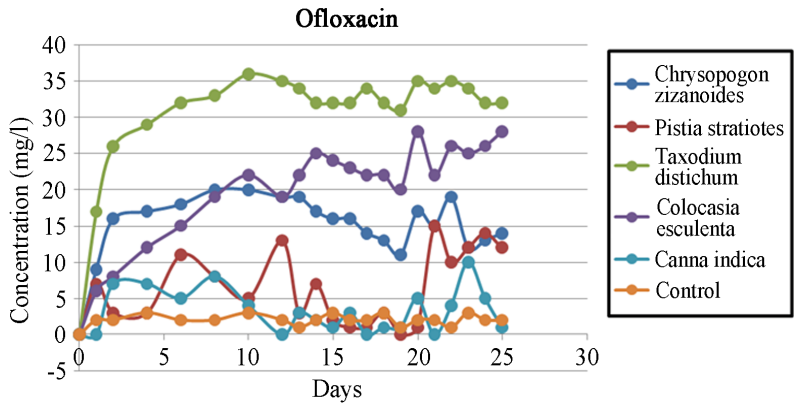

Figure 3. Ofloxacin removed (mg/l) from hydroponic system with various wetland plant species.

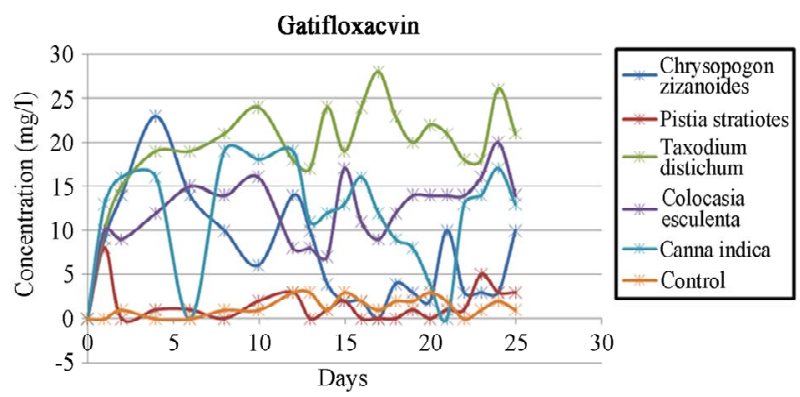

Figure 4. Gatifloxacin removed (mg/l) from hydroponic system with various wetland plant species.

antibiotics. As biochemical studies in different plant parts was not conducted it could not be ascertained whether the antibiotics were being accumulated or metabolized by the plants but the selected plant species were able to cause disappearance of the antibiotics from the solution at high concentration levels without any adverse effect on their growth and morphology. As these plant species were also found to be efficient in treating municipal waste waters, they can very well be used to treat municipal waste waters which contain these antibiotics.

\section{CONCLUSION}

In the present work, fluoroquinolones which are not degraded easily and remain in waste water for a long time, show potential to be removed in high concentra- 
tions by the selected wetland plant species (Taxodium distichum, Canna indica and Chrysopogon zizanioides) without any toxic effect as there was no adverse effect on their morphology and the plants grew well as indicated by increase in the weight. These wetland plant species were also able to treat municipal waste water effectively. Thus, the selected plant species, Taxodium distichum, Canna indica and Chrysopogon zizanioides, can be used to treat municipal waste water contaminated with the fluoroquinolone group of antibiotics and can be further used in our patented constructed wetland system (European Patent Office (EPO) Pub. No.: WO2004087584) or any other constructed wetland.

\section{REFERENCES}

[1] Vlsero, H.M., Fink, G., Schlusener, M.P., Sidrach-Cardona, R., Martin-Villacorta, J., Ternes, T. and Becares, E.1. (2011) Removal of antibiotics from urban wastewater by constructed wetland optimization. Chemosphere, 83, 713719.

http://dx.doi.org/10.1016/j.chemosphere.2011.02.004

[2] Daughton, C.G. and Ternes, T.A. (1999) Pharmaceuticals and personal care products in the environment; Agents of subtle change. Environmental Health Perspectives, 107, 907-938. http://dx.doi.org/10.1289/ehp.99107s6907

[3] Kolpin, D.W., Furlong, E.T., Meyer, M.T., Thurman, E.M., Zaugg, S.D., Barber, L.B. and Buxton, H.T. (2002) Pharmaceuticals, hormones and other organic wastewater contaminants in U.S. streams. A national reconnaissance. Environmental Science \& Technology, 36, 1202-1211. http://dx.doi.org/10.1021/es011055j

[4] Boxall, A.B.A. (2004) The environmental side effects of medication. EMBO Report, 5, 1110-1116. http://dx.doi.org/10.1038/sj.embor.7400307

[5] Sorensen, H.B., Nors, N.S., Lanzky, P.F., Ingerslev, F., Holten Lutzhoft, H.C. and Jorgensen, S.E. (1998) Occurrence, fate and effects of pharmaceuticals in the environment. Chemosphere, 36, 357-393.

http://dx.doi.org/10.1016/S0045-6535(97)00354-8

[6] Larsson, D.G., de Pedro, C. and Paxeus, N. (2007) Extremely high levels of pharmaceuticals. Journal of Hazardous Material, 148, 751-755.

http://dx.doi.org/10.1016/j.jhazmat.2007.07.008

[7] Stumpf, M., Ternes, T.A., Wilken, R.D., Rodrigues, S.V. and Baumann, W. (1999) Polar drug residue in sewage and natural waters in the State of Rio de Janeiro, Brazil. Science of the Total Environment, 225, 135-141. http://dx.doi.org/10.1016/S0048-9697(98)00339-8

[8] Lilienberg, M., Litvin, S.V., Nei, L., Roasto, M. and Sepp, K. (2010) Enrofloxacin and ciprofloxacin uptake by plants from soil. Agronomy Research, 8, 807-814.

[9] Ye, Z., Weinberg, H.S. and Meyer, M.T. (2007) Occurrence of antibiotics in drinking water. Analytical and Bioanalytical Chemistry, 387, 1365-1377.

[10] Kinney, C.A., Furlong, E.T., Werner, S.L. and Cahill, J.D. (2006) Presence and distribution of wastewater-derived pharmaceuticals in soil irrigated with reclaimed water. Environmental Toxicology Chemistry, 25, 317-326. http://dx.doi.org/10.1897/05-187R.1

[11] Kinney, C.A., Furlong, E.T., Kolpin, D.W., Burkhardt, M.R., Zaugg, S.D., Werner, S.L., Bossio, J.P. and Benotti, M.J. (2008) Bioaccumulation of pharmaceuticals and other anthropogenic waste indicators in earthworms from agricultural soil amended with biosolid or swine manure. Environmental Science and Technology, 42, 1863-1870. http://dx.doi.org/10.1021/es702304c

[12] Tshervjakova, V. and Terezova, A. (1986) Pharmacology and dispensary. Valgus, Tallinm, 98-112. (in Estonian)

[13] Marengo, J.R., Kok, R.A., O Brien, G.K., Velagaletti, R.R. and Stamm, J.L. (1997) Aerobic degradation of 14C- sarafloxacin hydrochloride in soil. Environmental Toxicology and Chemistry, 16, 462-471.

[14] Blanchard, J.S. (1996) Molecular mechanisms of drug resistance in Mycobacterium tuberculosis. Annual Review of Biochemistry, 65, 215-239.

http://dx.doi.org/10.1146/annurev.bi.65.070196.001243

[15] Hartmann, A., Alder, A.C., Koller, T. and Widmer, R.M. (1998) Identifications of fluoroquinolone antibiotics as the main source of umuC genotoxicity in native hospital wastewater. Environmental Toxicology Chemistry, 17, 377-382.

[16] Hartmann, A., Golet, E.M., Gartiser, S., Alder, A.C., Koller, T. and Widmer, R.M. (1999) Primary DNA dam- age but not mutagenicity correlates with ciprofloxacin concentrations in German hospital wastewater. Archives of Environmental Contamination and Toxicology, 36, 115119. http://dx.doi.org/10.1007/s002449900449

[17] Crowdy, S.H. and Pramer, D. (1955). Movement of antibiotics in higher plants. Chem. Ind., London, 160-162.

[18] Robinson, R.S., Starkey, R.L. and Davidson, O.W. (19540 Control of bacterial wilt of chrysanthemums with streptomycin. Phytopathology, 44, 646-650.

[19] Crowdy, S.H., Grove, J.F., Hemming, H.G. and Robinson, K.C. (1956) The translocation of antibiotics in higher plants. II. The movement of griseofulvin in broad bean and tomato. Journal of Experimental Botany, 7, 42-64. http://dx.doi.org/10.1093/jxb/7.1.42

[20] Sanwal, BD. (1956) Investigations on the metabolism of Fusarium lycopersci with the aid of radioactive carbon. Phytopathology, 25, 333-384.

[21] Sooknah, R. and Wilkie, A. (2004) Nutrient removal by floating aquatic macrophytes cultured anaerobically digested flushed dairy manure wastewater. Ecological Engineering, 22, 27-42.

http://dx.doi.org/10.1016/j.ecoleng.2004.01.004

[22] DeBusk, T., Peterson, J. and Ramesh, K. (1995) Use of aquatic and terrestrial plants for removing phosphorus from dairy wastewaters. Ecological Engineering, 5, 371390. http://dx.doi.org/10.1016/0925-8574(95)00033-X

[23] Qiming, X., Hu, L., Chen, H., Chang, Z. and Zou, H. (2010) Removal of nutrients and veterinary antibiotics from swine wastewater by a constructed macrophyte floating bed system. Journal of Environmental Management, 91, 2657-2661. 
http://dx.doi.org/10.1016/j.jenvman.2010.07.036

[24] Dey, S., Ratnakar, C.H. ,Vaithiyanathan, S., Samal, H.B, Reddy, Y.V., Krishna Bala, Reddy, Y.A., Kumar, N. and Mohapatra, S. (2010) Spectrophotometer method developed for the estimation of flucloxacilin in bulk and dosage form using UV-VIS spectrophotometric method. International Journal of Pharma and Biosciences, 1, 35.

[25] Mendez, A.S., Steppe, M. and Schapoval, E.E. (2003) Validation of HPLC and UV spectrophotometric methods for the determination of meropenem in pharmaceutical dosage form. Journal of Pharmaceutical and Biomedical Analysis, 33, 947-954.

http://dx.doi.org/10.1016/S0731-7085(03)00366-2

[26] McCutcheon, S. (2003) Phytoremediation. John Wiley \& Sons, Hoboken, 898.

[27] http://plant-materials.nrcs.usda.gov/pubs/etpmcbrconwet. pdf

[28] American Public Health Association-American Water Works Association-Water Environment Federation (APHA-
AWWA-WEF) (1995) Standard methods for the examination of water and wastewater. 20th Edition, American Public Health Association, American Water Works Association-Water Pollution Control Fed, Washington DC.

[29] Larsson, D.G., de Pedro, C. and Paxeus, N. (2007) Extremely high levels of pharmaceuticals. Journal of Hazardous Material, 148, 751-755. http://dx.doi.org/10.1016/i.jhazmat.2007.07.008

[30] Shaibur, M.R. and Kawai, S. (2010) Effect of arsenic on nutritional composition of Japanese mustard Spinach: An Ill effect of arsenic on nutritional quality of a green leafy vegetable. Nature and Science, 8, 186-194.

[31] Amjad, H., Iqbal, J. and Naeem, M. (2005) Analysis of some residual antibiotics in muscle, kidney and liver samples of broiler chicken by various methods. Proceedings of the Pakistan Academy of Sciences, 42, 223-231. 